Jurnal Infotekmesin Vol.9 No.2 Juli 2018

\title{
PENERAPAN ANALYTIC NETWORK PROCESS (ANP) DALAM MENENTUKAN PRESIDEN REPUBLIK INDONESIA BAGI GENERASI MILENIAL PADA PEMILU 2019
}

\author{
Lutfi Syafirullah, Annas Setiawan Prabowo
}

Program Studi Teknik Informatika, Politeknik Negeri Cilacap

Program Studi Teknik Informatika, Politeknik Negeri Cilacap syafirullah.lutfi@gmail.com, annassetiawanp@gmail.com

\begin{tabular}{|c|c|}
\hline & Abstrak \\
\hline $\begin{array}{l}\text { Kata Kunci: } \\
\text { Pemilu, pengambilan } \\
\text { keputusan, ANP } \\
\text { (Analytic Network } \\
\text { Process) dan super } \\
\text { decision }\end{array}$ & $\begin{array}{l}\text { Pemilihan umum atau pemilu merupakan salah satu bagian dalam sistem demokrasi untuk } \\
\text { memilih wakil rakyat di lembaga perwakilan rakyat. Bangsa Indonesia pada tanggal } 17 \text { April } \\
2019 \text { akan melaksanakan mekanisme pergantian kekuasaan (suksesi) pemilu untuk menentukan } \\
\text { presiden periode 2019-2023. Makalah ini membahas mengenai pengambilan keputusan untuk } \\
\text { memilih calon presiden RI 2019. Penulis menggunakan metode Analytic Network Process(ANP) } \\
\text { dan dibantu software super decision untuk melihat nilai konsistensi dari masing-masing tabel } \\
\text { perbandingan. Metode ini diharapkan dapat membantu semua pihak khususnya generasi } \\
\text { milennial di Indonesia untuk mengetahui faktor-faktor apa sajakah yang menjadi pertimbangan } \\
\text { dalam memilih calon presiden dan wakil presiden RI 2019. Adapun objek penelitian adalah } \\
\text { mahasiswa Politeknik Negeri Cilacap Jurusan Teknik Informatika angkatan 2018. Dari hasil } \\
\text { penelitian didapatkan bahwa faktor utama dalam memilih presiden dan wakil presiden adalah } \\
\text { merakyat dan pasangan Jokowi-Ma'ruf merupakan pasangan yang dipilih kaum milenial } \\
\text { karena merakyat. }\end{array}$ \\
\hline
\end{tabular}

\section{Abstract}

Keywords:

Elections, decision making, ANP (Analytic Network Process) and super decision

\begin{abstract}
General elections or elections are one part of the democratic system to elect representatives in the people's representative institutions. The Indonesian nation on April 17, 2019 will implement a mechanism for the succession of elections to determine the president for the period 20192023. This paper discusses the decision making to elect the 2019 RI presidential candidate. The author uses the Analytic Network Process (ANP) method and is assisted by super decision software to see the consistency values of each comparison table. This method is expected to be able to help all parties, especially the millennial generation in Indonesia, to find out what factors are taken into consideration in choosing RI 2019 presidential and vice presidential candidates. The object of the research is the Cilacap State Polytechnic student of the Informatics Engineering Department in 2018. that the main factor in choosing the president and vice president is popularization and the Jokowi-Ma'ruf pair is a pair chosen by millennials because they are populist.
\end{abstract}

\footnotetext{
${ }^{\square}$ Alamat korespondensi :

E-mail : nadhifaoo7@gmail.com

ISSN : 2087-1627
} 


\section{Pendahuluan}

Bangsa Indonesia akan melaksanakan pesta demokrasi pemilu pilpres (pemilihan presiden) yang akan dilaksanakan pada 17 April 2019. Sebanyak 14 partai politik yang terbagi dalam dua koalisi mulai menyusun berbagai strategi menghadapi pemilu pilpres dalam mengusung pasangan presiden dan wakil presiden pada pemilu pilpres 2019. Joko Widodo dan Ma'ruf Amin adalah calon presiden dan wakil presiden yang diusung oleh PDI-P, Golkar, Nasdem, PKB, PPP, Hanura, PKP, PSI dan Perindo yang tergabung dalam Koalisi Kerjasama Partai Pendukung Pemerintah (KP3). Sedangkan Prabowo dan Sandiaga Uno adalah calon presiden dan wakil presiden yang di usung oleh Gerindra, Demokrat, PAN, PKS dan Berkarya yang tergabung dalam Koalisi Merah Putih.

Generasi milenial atau kadang juga disebut dengan generasi $\mathrm{Y}$ adalah sekelompok orang yang lahir setelah Generasi X pada kisaran tahun 19802000an. Hal ini berarti milenial adalah generasi muda yang berumur 17- 37 pada tahun ini dan dianggap spesial dibanding dengan generasi sebelumnya terutama karena generasi ini sangat mahir dalam teknologi terutama dalam hal mendapatkan informasi. Di Indonesia 81 juta penduduk merupakan generasi milenial dari total 255 juta jumlah penduduk. Memilih pemimpin tentu bukan hal yang mudah khususnya bagi generasi milenial karena tidaklah mudah mendapatkan informasi valid, hal ini disebabkan banyak informasi bohong (hoax) bersebaran terutama di media sosial sehingga pemilih milenial harus dapat menganalisa dan berhati-hati dalam memberikan suara bagi calon presiden yang akan memimpin bangsa ini hingga lima tahun kedepan.

Berdasarkan uraian diatas maka diperlukan berbagai masukan atau pertimbangan yang dapat dijadikan patokan bagi setiap warga negara dalam menggunakan hak suara untuk menentukan pilihan pasangan mana yang layak menjadi presiden RI 2019-2023 antara pasangan Jokowi-Ma'ruf ataukah Prabowo-Sandiaga.

Yang menjadi latar belakang permasalahan dalam makalah ini adalah faktor apa sajakah yang menjadi pertimbangan bagi generasi milenial dalam memilih pasangan presiden dan wakil presiden Republik Indonesia tahun 2019 Jokowi-Ma'ruf ataukah Prabowo-Sandiaga. Dalam makalah ini proses pemilihan presiden dilakukan dengan membandingkan beberapa parameter diantaranya: merakyat, ketegasan, kejujuran dan pengalaman.

Tujuan dari penelitian ini adalah untuk mengetahui faktor-faktor apa sajakah yang menjadi pertimbangan bagi generasi milenial dalam memilih calon presiden dan wakil presiden RI 2019.

Metode Analityc Network Process merupakan salah satu metode yang dapat mempresentasikan tingkat kepentingan berbagai pihak yang terlibat dengan mempertimbangan saling keterkaitan antara strategi objektif yang satu dengan objek yang lain. Metode ini adalah pengembangan dari metode Analytic Hierarchy Process (AHP). Metode Analitycal Hierarki Process (AHP) merupakan metode pembobotan yang lazim digunakan dalam merancang sebuah sistem pengukuran kinerja. Metode ini biasanya menggunakan asumsi suatu strategi objektif didalam setiap perspektif yang saling independent satu dengan lainnya yang direpresentasikan menggunakan struktur hierarki.

ANP merupakan salah satu metode yang rumit dan kompleks karena metode ini memiliki banyak tahapan untuk hasil akhirnya. Karena ANP adalah teori umum pengukuran relative yang digunakan untuk menurunkan rasio prioritas komposit dari skala rasio individu yang mencerminkan pengukuran relative dari pengaruh elemen-elemen yang saling berinteraksi berkenaan dengan kriteria kontrol (Saaty, 2005). ANP adalah teori matematika yang memungkinkan semua pihak untuk melakukan dependence dan feedback secara sistematis yang kemudian dapat menangkap serta mengkombinasikan faktor-faktor tangible dan intangible (Aziz, 2003).

Manfaat yang hendak dicapai dalam penulisan makalah ini adalah:

\section{A. Bagi Penulis}

Menambah wawasan penulis tentang faktor apa saja yang dijadikan pertimbangan khususnya generasi milenial dalam memilih calon presiden dan wakil presiden RI 2019.

\section{B. Bagi Pembaca}

Hasil penulisan makalah ini diharapkan dapat menjadi masukan bagi para pembaca khususnya generasi milenial untuk dapat menganalisa berbagai faktor yang harus dipertimbangkan dalam memilih calon presiden dan wakil presiden RI 2019 nanti.

\section{Tinjauan Pustaka}

Berikut ini adalah beberapa makalah terdahulu yang berkaitan dengan tema ANP dalam pengambilan keputusan:

A. Analytical Network Process (ANP) pada sistem pengukuran kinerja di kebun sidamanik pematang siantar (Hidayati Juliza, 2012). Makalah ini membahas 
tentang kemampuan yang dimiliki perusahaan dalam menerapkan strategi efektif demi memastikan tujuan yang ingin dicapai oleh perusahaan. Untuk mencapai suatu tujuan yang diharapkan, perusahaan wajib meningkatkan kinerja dari periode ke periode selanjutnya. Kebun sidamanik pematang siantar ptp nusantara iv (persero) adalah salah satu perusahaan yang bergerak dibidang industry dengan memproduksi teh yang dipasarkan baik di dalam negeri maupun luar negeri. Siring berkembangnya persaingan dalam dunia industri yang semakin ketat, kebun sidamanik pematang siantar terus berupaya meningkatkan kinerja perusahaan agar dapat bertahan di pasar global sehingga diperlukan pengukuran kinerja agar dapat diketahui perkembangan kemajuan perusahaan tersebut. Pada penelitian ini, dilakukan pengukuran kinerja untuk mengetahui besarnya (\%) kinerja perusahaan di kebun sidamanik pematang siantar ptp iv (persero), sehingga dapat dirumuskan kebijakan (strategi) dalam mencapai tujuan perusahaan. Pemecahan masalah perhitungan besarnya kinerja (\%) menggunakan metode ANP (Analytic Network Procces), dimana dengan metode ANP pengukuran kinerja dilakukan dengan memperhatikan saling keterkaitan antara strategi objektif-objektif yang satu dengan yang lain dengan membandingkan beberapa kriteria. Kebun sidamanik pematang siantar ptp iv (persero) memiliki empat perspektif sebagai berikut finansial (27.1\%), pelanggan (46.4\%), proses bisnis internal (9\%) serta pertumbuhan dan pembelajaran (17.6\%). Dari perhitungan diperoleh besarnya kinerja dari masingmasing strategi objektif di kebun sidamanik pematang siantar ptp nusantara iv (persero) yaitu bisnis growth $(4.9 \%)$, profitabilitas $(6.4 \%)$, solvabilitas $(4.3 \%)$, biaya operasional $(5.5 \%)$, pendapatan operasi (4.7\%), kepuasan pelanggan $(6.8 \%)$, peningkatan jumlah pelanggan (7.9\%), karakteristik produk (7.8\%), kemajuan teknologi (4.1\%), ramah lingkungan (5.9\%), maintenance (5.8\%), peningkatan $\mathrm{k} 3 \quad(5.6 \%)$, optimalisasi penjualan $(4.5 \%)$, jumlah tenaga kerja ahli (3.6\%), performance appraisal (6.2\%), pelatihan teknologi informasi (4.7\%), sistem informasi (7.4) dan inovasi (4\%).

B. Metode Analytic Network Process (ANP) dalam menentukan Supplier Bahan Baku Kertas di PT. Mangle Panglipur (Alfian, Ignatius A. Sandy, Hanif Fathurahman,
2013). Makalah ini membahas tentang pengambilan keputusan dalam menentukan supplier terbaik bagi perusahaan di PT Mangle Panglipur. PT Mangle Panglipur merupakan perusahaan yang menerbitkan majalah berbahasa Sunda dan berdiri sejak 21 November 1957. Dalam menerbitkan suatu majalah, dibutuhkan berbagai bahan baku diantaranya kertas. Dalam memilih supplier untuk memasok kertas, perusahaan masih menerapkan cara konvensional. Pemilihan supplier yang tidak tepat berdampak pada nilai penjualan karena berhubungan dengan proses produksi dan tentunya berhubungan dengan produk yang akan dijual nantinya. Banyak hal yang harus dipertimbangkan dalam memilih supplier. Proses pengambilan keputusan dalam memilih supplier harus diperhatikan faktor-faktor (kriteria) satu dengan lainnya dikarenakan saling terkait. Metode Analytic Network Process (ANP) merupakan metode pengambilan keputusan dengan menggunakan banyak kriteria yang saling terkait. Permasalahan ini direpresentasikan oleh sebuah sistem dengan ketergantungan (dependence) dan feedback. Keterkaitan yang terdapat didalam metode ANP adalah keterkaitan didalam satu set elemen (node comparison) dan keterkaitan terhadap elemen yang berbeda (cluster comparison). Penggunaan metode ANP menghasilkan bobot nilai prioritas pada seluruh elemen yang digunakan dalam pengambilan keputusan. Dari penelitian yang telah dilakukan di PT. Mangle Panglipur terdapat 4 kriteria pertimbangan diantaranya terdiri dari 12 sub-kriteria dan 3 alternatif pilihan. Berdasarkan hasil pengolahan data, CV Karya Jaya terpilih sebagai alternatif supplier terbaik dengan bobot tertinggi sebesar 0,158 kemudian diikuti CV Makmur Jaya dengan bobot 0,145 dan CV Sinar Jaya dengan bobot sebesar 0,134. Maka dari itu dapat disimpulkan bahwa CV Karya Jaya merupakan alternatif supplier terbaik bagi pihak perusahaan.

\section{Metodologi Penelitian}

Pada penelitian ini penulis mengambil sampel generasi milenial terhadap mahasiswa jurusan teknik informatika angkatan 2018 dengan jumlah total populasi 96 mahasiswa. Adapun total sampel sebanyak 77 mahasiswa diambil dengan metode random sampling (acak) 
dengan tingkat kesalahan 5\% yang diperoleh dengan rumus:

$$
\mathrm{n}=\frac{N}{1+N e^{2}}
$$

Dimana:

$$
\begin{array}{ll}
\mathrm{n} & =\text { sampel } \\
\mathrm{N} & =\text { populasi } \\
\mathrm{e} & =\text { error/tingkat kesalahan }
\end{array}
$$

Adapun pengambilan data dilakukan dengan dua tahap yaitu:

\section{A. Wawancara}

Pada tahap ini penulis melakukan wawancara terhadap mahasiswa Politeknik Negeri Cilacap Jurusan Teknik Informatika angkatan 2018.

\section{B. Kuisioner}

Melakukan pengambilan data dengan membagikan kuisioner terhadap 20 sampel mahasiswa Politeknik Negeri Cilacap Jurusan Teknik Informatika angkatan 2018.

\section{Hasil dan Pembahasan}

Dalam penelitian ini penulis mendeskripsikan terlebih dahulu permasalahan yang akan dihadapi dan dipecahkan dengan membangun cluster dan node (yang mewakili masing-masing cluster). Dimana permasalahan penelitian ini adalah mencari faktor-faktor yang digunakan dalam memilih pasangan calon presiden dan wakil presiden Republik Indonesia 2019. Langkah selanjutnya adalah penggambaran cluster dan node menggunakan software super decisions yang nantinya digunakan dalam melihat output dari hasil pengolahan data kuisioner. Langkah awal yang dilakukan adalah menciptakan cluster (tujuan, kriteria dan alternatif) beserta node-node yang mewakili tiap cluster (memilih calon Presiden RI 2019, merakyat, ketegasan, jujur, pengalaman, Prabowo-Sandiaga, dan Jokowi-Ma'ruf). Cluster-cluster yang telah diciptakan selanjutnya di hubungkan secara top-down dan juga botton-up sesuai prinsip kerja metode Analytic Network Process (ANP).

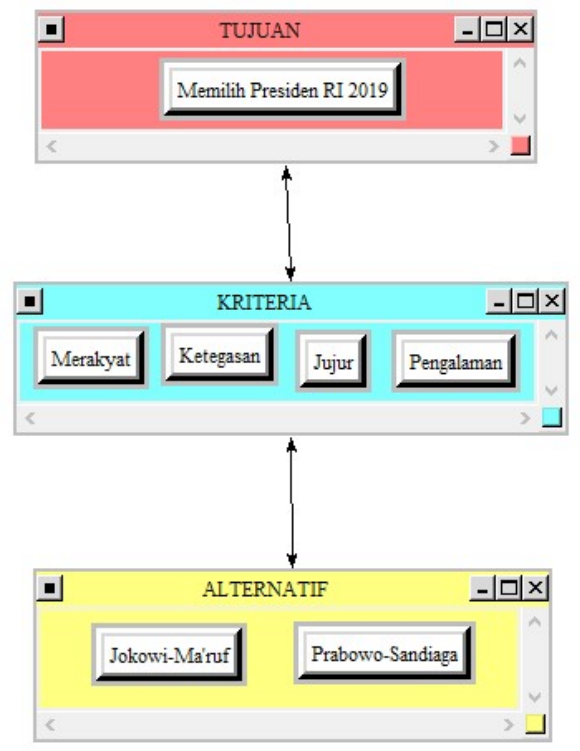

Gambar 4.1 Hubungan Cluster dan Node

Setelah menentukan hubungan antara cluster tujuan, kriteria dan alternatif, langkah selanjutnya adalah melakukan komparasi antara node memilih calon presiden RI 2019 dalam cluster tujuan dengan node merakyat, node ketegasan, node jujur dan node pengalaman dalam cluster kriteria.

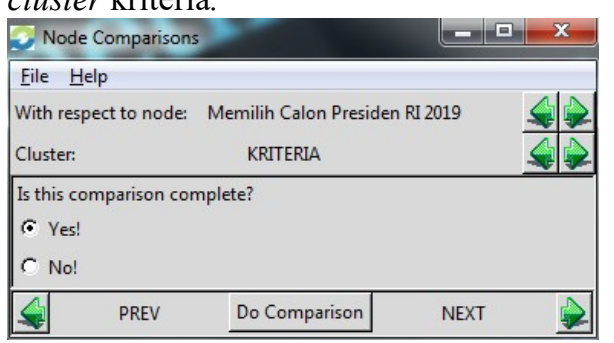

Gambar 4.2 Komparasi Node Tujuan dan Node Kriteria

Data kuisioner yang telah diolah diinputkan untuk membandingkan nilai merakyat, ketegasan, jujur dan pengalaman sehingga dapat dilihat nilai inkonsistensinya.

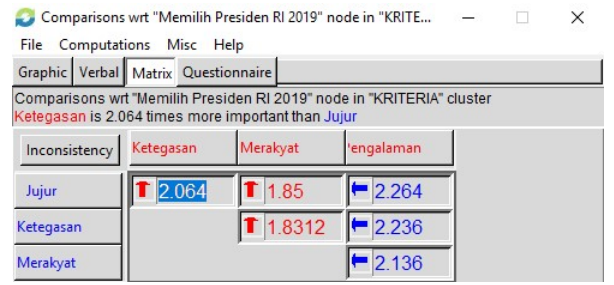

Gambar 4.3 Komparasi Matrik Kriteria

Dari hasil perhitungan dapat dilihat nilai inkonsistensi komparasi antara merakyat, ketegasan, jujur dan pengalaman dimana merakyat merupakan prioritas tertinggi 
yang dipilih oleh responden mahasiswa Teknik Informatika Politeknik Negeri Cilacap angkatan 2018 pada Pilpres RI 2019.

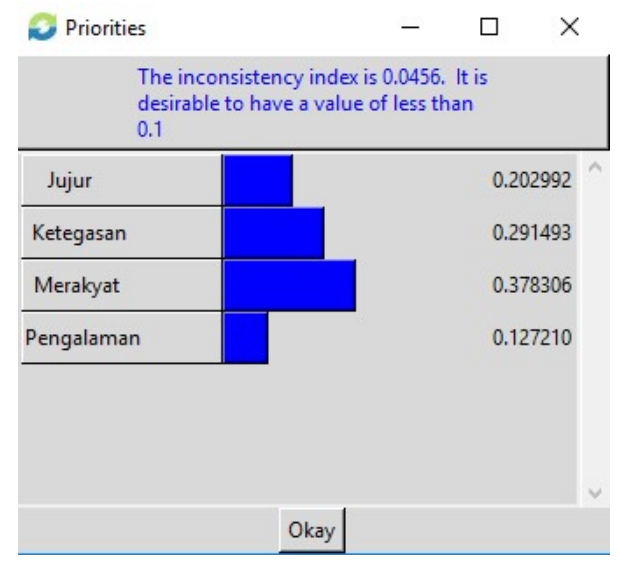

Gambar 4.4 Nilai Prioritas Kriteria Pembanding

Langkah selanjutnya adalah melakukan komparasi antara node merakyat dalam cluster kriteria dengan setiap node dalam dalam cluster alternatif.

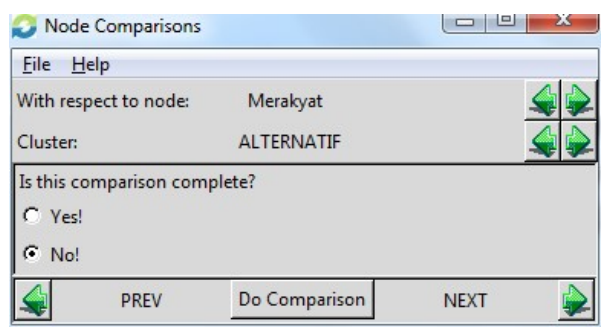

Gambar 4.5 Komparasi Node Merakyat dan Node Alternatif

Data kuisioner yang telah diolah diinputkan untuk membandingkan nilai merakyat antara pasangan PrabowoSandiaga dengan pasangan JokowiMa'ruf.

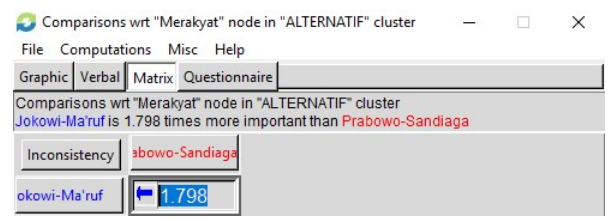

Gambar 4.6 Komparasi Matrik AlternatifMerakyat

Dari hasil perhitungan dapat dilihat bahwa pasangan Jokowi-Ma'ruf lebih merakyat dibandingkan pasangan Prabowo-Sandiaga pada pilpres RI 2019.

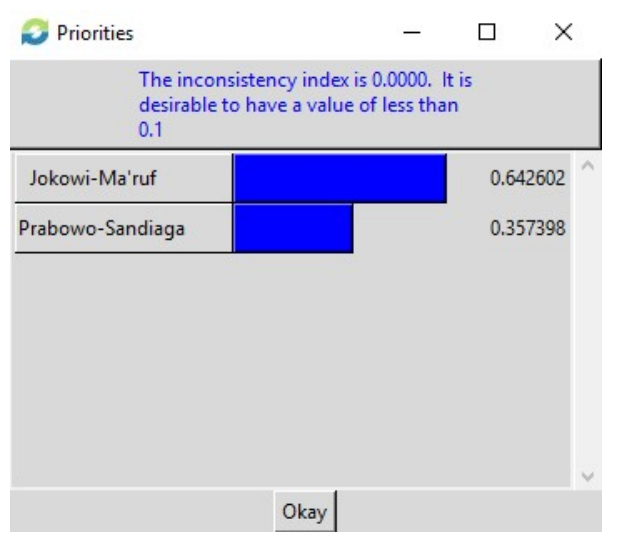

Gambar 4.7 Nilai Prioritas Kriteria Merakyat

Langkah selanjutnya adalah melakukan komparasi antara node ketegasan dalam cluster kriteria dengan setiap node dalam dalam cluster alternatif.

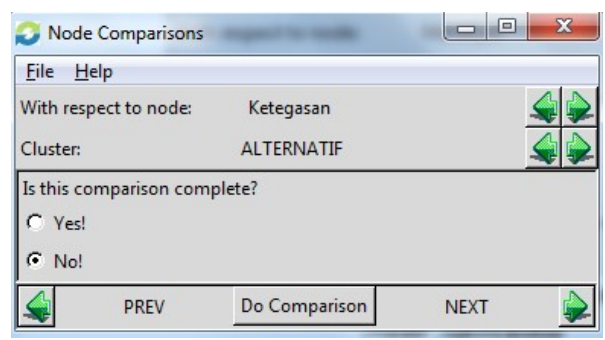

Gambar 4.8 Komparasi Node Ketegasan \& Node Alternatif

Data kuisioner yang telah diolah diinputkan untuk membandingkan nilai ketegasan antara pasangan PrabowoSandiaga dengan pasangan JokowiMa'ruf.

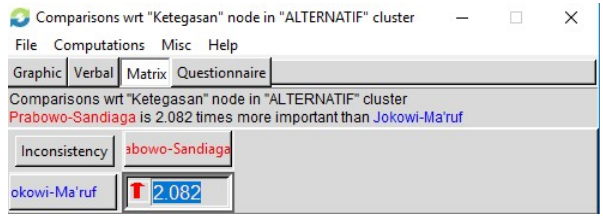

Gambar 4.9 Komparasi Matrik Alternatif Ketegasan

Dari hasil perhitungan dapat dilihat bahwa pasangan Prabowo-Sandiaga lebih tegas dibandingkan pasangan Jokowi-Ma'ruf pada pilpres RI 2019. 


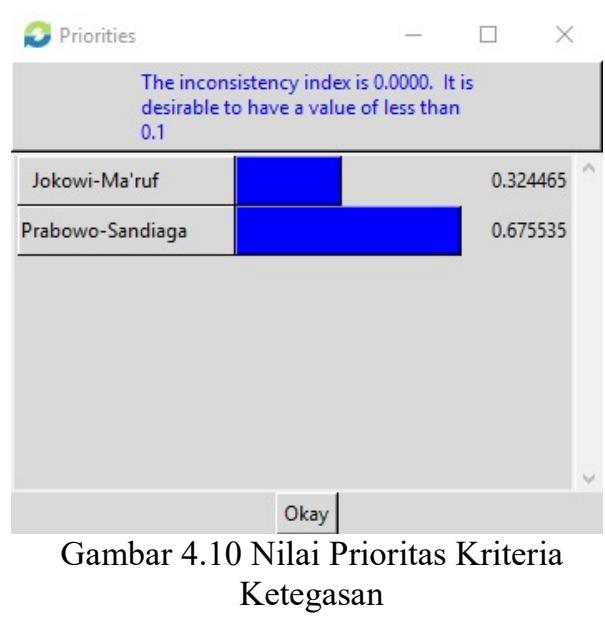

Langkah selanjutnya adalah melakukan komparasi antara node kejujuran dalam cluster kriteria dengan setiap node dalam dalam cluster alternatif.

\begin{tabular}{|c|c|c|}
\hline 3 Node Comparisons & 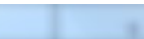 & \begin{tabular}{|l|l|l|}
0 & 回 & $x$ \\
\end{tabular} \\
\hline \multicolumn{3}{|l|}{ File Help } \\
\hline With respect to node: & Jujur & $\leqslant \Leftrightarrow$ \\
\hline Cluster: & ALTERNATIF & $\Leftrightarrow \theta$ \\
\hline \multicolumn{3}{|c|}{$\begin{array}{l}\text { Is this comparison complete? } \\
\text { C Yes! } \\
\text { C No! }\end{array}$} \\
\hline$\leq$ & Do Comparison & NEXT \\
\hline
\end{tabular}

Gambar 4.11 Komparasi Node Kejujuran \& Node Alternatif

Data kuisioner yang telah diolah diinputkan untuk membandingkan nilai kejujuran antara pasangan PrabowoSandiaga dengan pasangan JokowiMa'ruf.

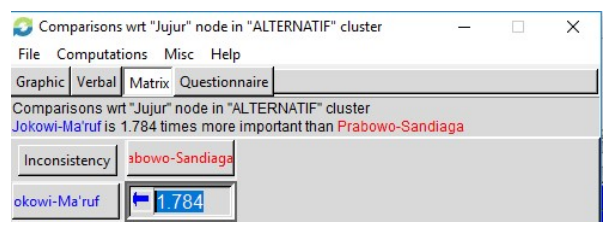

Gambar 4.12 Komparasi Matrik Alternatif - Kejujuran

Dari hasil perhitungan dapat dilihat bahwa pasangan Jokowi-Ma'ruf lebih jujur dibandingkan pasangan Prabowo-Sandiaga pada pilpres RI 2019.

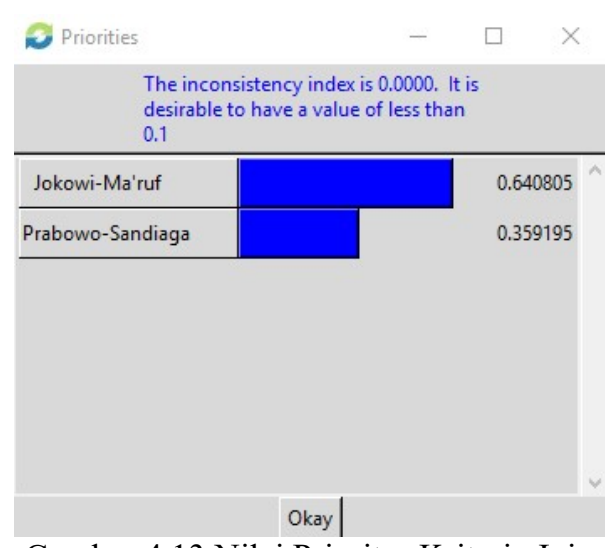

Gambar 4.13 Nilai Prioritas Kriteria Jujur

Langkah selanjutnya adalah melakukan komparasi antara node pengalaman dalam cluster kriteria dengan setiap node dalam dalam cluster alternatif.

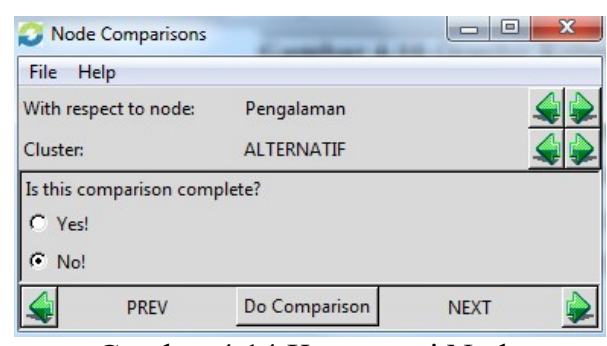

Gambar 4.14 Komparasi Node Pengalaman \& Node Alternatif

Data kuisioner yang telah diolah diinputkan untuk membandingkan nilai pengalaman antara pasangan PrabowoSandiaga dengan pasangan JokowiMa'ruf.

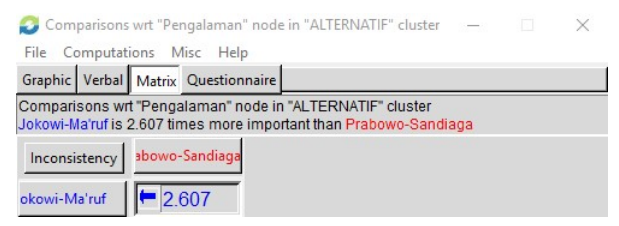

Gambar 4.15 Komparasi Matrik Alternatif - Pengalaman

Dari hasil perhitungan dapat dilihat bahwa pasangan Jokowi-Ma'ruf lebih berpengalaman dibandingkan pasangan Prabowo-Sandiaga pada pilpres RI 2019. 


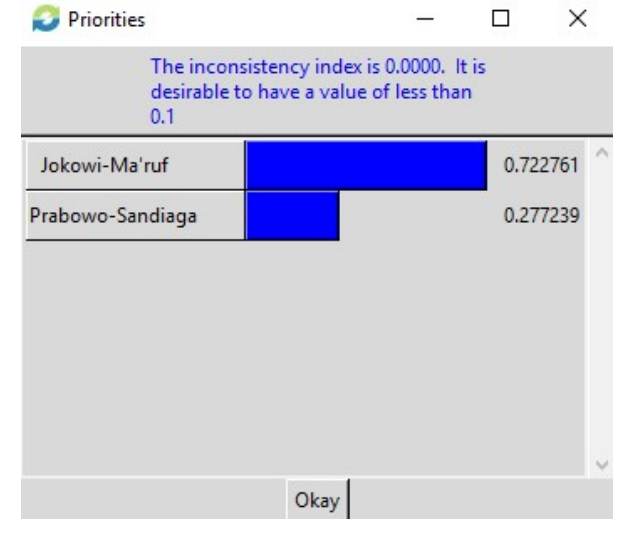

Gambar 4.16 Nilai Prioritas Kriteria Pengalaman

Berikut matrik perbandingan seluruh node pada masing-masing cluster (tujuan, kriteria dan alternative) yang didapatkan dari metode Analytic Network Prosess.

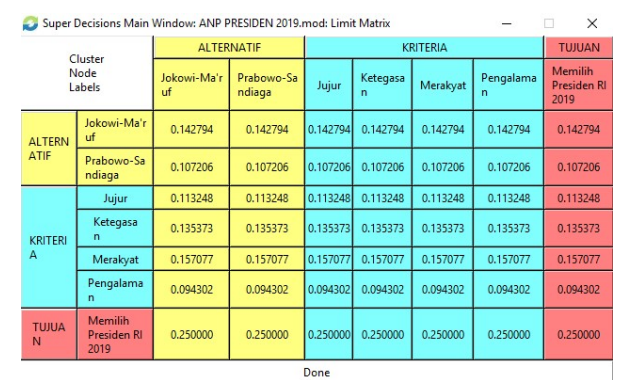

Gambar 4.17. Komparasi Matrik ANP

Secara keseluruhan dapat dilihat bahwa yang menjadi faktor utama bagi generasi milenial yang diambil dari sampel mahasiswa Politeknik Negeri Cialacap Jurusan Teknik Informatika angkatan 2018 dalam Pilpres RI 2019 adalah faktor merakyat, kemudian diikuti faktor ketegasan, kemudian faktor kejujuran kemudian faktor pengalaman. Sedangkan yang menjadi pilihan untuk menjadi Presiden dan Wakil Presiden RI 2019 adalah Jokowi-Ma'ruf seperti terlihat pada gambar berikut.

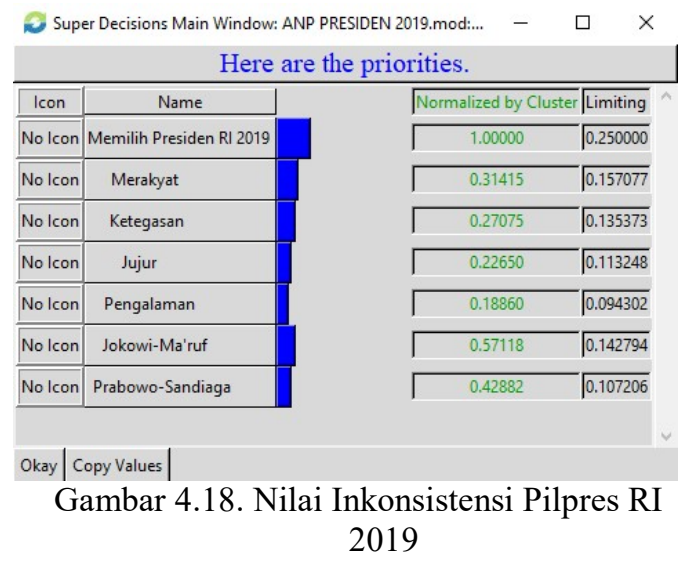

\section{Kesimpulan} berikut:

Hasil penelitian dapat disimpulkan sebagai

1. Faktor utama dalam pilpres adalah merakyat.

2. Pasangan Jokowi-Ma'ruf merupakan pasangan yang dipilih kaum milenial karena merakyat.

\section{Daftar Pustaka:}

[1] Hidayati, J., "Analytical Network Process (ANP) pada sistem pengukuran kinerja di kebun sidamanik pematang siantar," Jurnal Teknik Industri, Vol. VII, No 1, 2012.

[2] Alfian, Ignatius A.S., dan Fathurahman H., "Metode Analytic Network Process (ANP) dalam menentukan Supplier Bahan Baku Kertas ", Jurnal Rekayasa Sistem Industri, vol. 2, No.1, 2013.

[3] Saaty, T. L., "Creative Thinking, Problem Solving \& Decision Making," RWS Publ., ISBN-1-888603-03-8,2005.

[4] Azis, I. J., "Analytic network process with feedback influence: a new approach to impact study, Prepared for a seminar organized by the Department of Urban and Regional Planning," Jurnal Transformatika, vol. 14, 2003. 